\title{
Primer-Like Inhibitors for DNA Repair Enzymes of the AML-HL60 and WERI-1A/Y79 Malignant Cells
}

\section{Sergei V. Stovbun1, Kirill V. Ermakov2*, Alexander A. Bukhvostov², Alexander S. Vedenkin1, Dmitry A. Kuznetsov ${ }^{1,2}$}

${ }^{1}$ N.N. Semenov Institute of Chemical Physics, Russian Academy of Sciences, Moscow, Russia

${ }^{2}$ Faculty of Biomedicine, N.I. Pirogov Russian National Research Medical University, Moscow, Russia

Email: ${ }^{\star}$ ermakovkv07@gmail.com

How to cite this paper: Stovbun, S.V., Ermakov, K.V., Bukhvostov, A.A., Vedenkin, A.S. and Kuznetsov, D.A. (2019) Primer-Like Inhibitors for DNA Repair Enzymes of the AML-HL60 and WERI-1A/ Y79 Malignant Cells. Advances in Enzyme Research, 7, 27-44.

https://doi.org/10.4236/aer.2019.73003

Received: August 6, 2019

Accepted: September 24, 2019

Published: September 27, 2019

Copyright $\odot 2019$ by author(s) and Scientific Research Publishing Inc. This work is licensed under the Creative Commons Attribution International License (CC BY 4.0).

http://creativecommons.org/licenses/by/4.0/

(c) (i) Open Access

\begin{abstract}
A conventionally synthesized thio- and cyano-modified single-stranded poly (dNTP) sequences of different molecular sizes $(20 n-200 n)$ and the same lengths routine poly(dNTP) and poly(NTP) species were obtained through the good services provided by the Russian Federal Bioorganic Products Group and by the ThermoFischer, Inc., and then tested for their impact on catalytic activities of $\beta$-like DNA polymerases from chromatin of HL-60, WERI-1A and Y-79 cells as well as for the affinity patterns in DNApol $\beta$-poly(dNTP)/ (NTP) pairs, respectively. An essential link between the lengths of ultrashort $(50 n-100 n)$ single-stranded poly(dNTP) sequences of different structures and their inhibitory effects towards the cancer-specific DNA polymerases $\beta$ has been found. A possible significance of this phenomenon for both DNA repair suppression in tumors and a consequent anti-cancer activity of the DNA repair related short poly(dNTP) fragments has been for the first time emphasized with a respect to their pharmacophore revealing potential. Thus, this work presents an experimental attempt to upgrade a contemporary attitude towards the DNA derived products applied for anti-cancer agenda, particularly, for acute myeloid leukemia and retinoblastoma cell DNA repair machinery breakdown. In this study, tumor specific DNA polymerases $\beta$ were found of being the targets for attack promoted with the primer-like single-stranded DNA fragments followed by consequent cytostatic phenomena. A novel concept of the DNA related anti-cancer medicines is under discussion.
\end{abstract}

\section{Keywords}

Magnetic Isotope Effects (MIE), DNA Repair, DNA Polymerases, DNA-Enzyme Binding 


\section{Introduction}

A background-lying platform of this work derives from experimental data on magnetic isotope effects (MIE) towards both DNApol $\beta$ catalytic activity [1] [2] [3] and the viability of cancer cells [1] [2]. Thus, a sharp decrease of the survival ability patterns of ${ }^{25} \mathrm{Mg}^{2+}$-treated AML/HL-60 cells as compared to abundant spinless, non-magnetic, magnesium ions impact has been found [1]. Furthermore, a similar result was then obtained on the same leukemia cells treated with magnetic, nuclear spin possessing, ${ }^{43} \mathrm{Ca}^{2+}$ and ${ }^{67} \mathrm{Zn}^{2+}$ ions [1] [3] as well as on human retinoblastoma cells subjected to these metal isotopes [2] [3].

It was also shown that a processivity of beta-like DNA polymerases isolated from the all above mentioned malignant cells depends on MIE, so the resulted DNA fragment sizes becomes shorter within a $40 n-250 n$ range following the increase of magnetic isotope content in a total metal pool [2] [3]. For instance, an up to $58 \%$ elevation of ${ }^{43} \mathrm{Ca}^{2+}$ content leads to a monotonic decrease of sizes of polynucleotides processed from average $230 n-250 n$ to an abnormal (DNA repair invalid) $36 n-40 n$ as directed by beta-like DNA polymerases from Y-79 and WERI-1A retinoblastoma cells [1].

This nuclear-magnetic control over the DNA synthesis, therefore, allows coming up with a firm statement that a replication mechanism involves some ion-radical steps consisting of the ion-radical pairs formation [1]. A key element of this mechanism deals with an electron transfer from the nascent DNA deoxyribose anion to a bivalent ion coordinated inside the DNA polymerase catalytic site [1] [4] (Figure 1).

However, from the chemical physics point of view, it is still obscure what makes the difference between molecular dynamics designs of these ion-radical DNA synthesis paths processed in healthy and malignant cells. Noteworthy, within the DNApol $\beta$ catalytic site nanotopology landscape which provides a

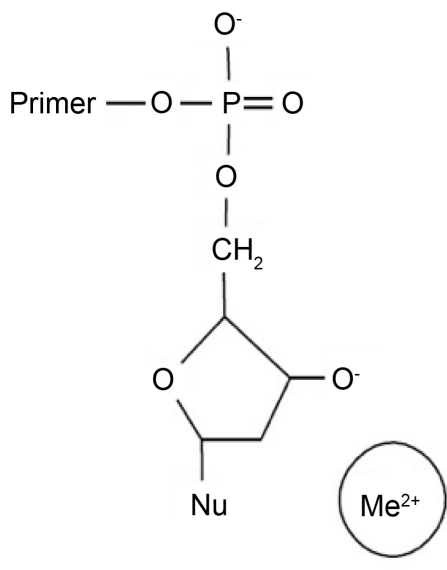

DNA Strand

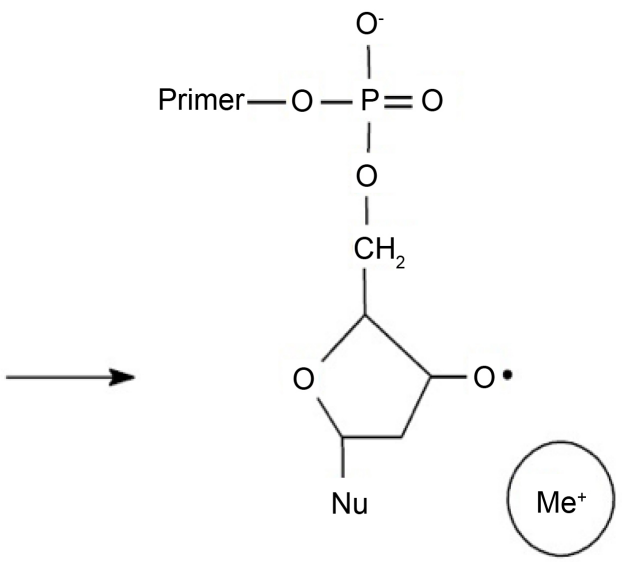

DNA Strand

Figure 1. A reaction of electron transfer from the nascent DNA deoxyribose anion to a bivalent metal ion. 
“compartment" for this reaction (10 - $15 \mathrm{~nm}$ or less), all physical parameters describing a molecular machinery in normal and cancer cells at proliferation rates observed are identical or pretty close to each other [5]-[10].

Obviously, the DNA synthesis reaction [1] [2] [3] is unlikely a source for apoptosis of tumor cells as relates to dependence of their viability on MIE [1]. Nonetheless, this MIE-viability dependence might have a link to DNA repair activity expressed by beta-like DNA polymerases in neoplasma [2] [3] [11].

According to our assumption, these enzymes are to produce the ultrashort PDRN sequences $(\approx 40 n)$ playing a role of DNApol $\beta$ inhibitors. Acting as the DNA repair limiting/damaging factors, these endogenous inhibitors may promote an essential anti-cancer effect. In case of ${ }^{25} \mathrm{Mg} /{ }^{43} \mathrm{Ca} /{ }^{67} \mathrm{Zn}$-induced impacts on enzymatic activity in situ, these inhibitors might be originated as a direct response to MIE.

Moreover, due to a random mode of the cancer-specific repair-required local DNA damages, the DNA repair itself means a wide variability in primary structures of the repair-related PDRN species. This also means that the PDRN inhibitory function should be determined predominantly, if not exclusively, by the lengths of these sequences. These lengths alone might determine not only the molecular dynamics in DNApol $\beta$-PDRN docking pairs but, simultaneously, they might make an impact on specific Coulomb and dispersion couplings and, hence, on the mean amounts of hydrogen bonds per one nucleotide of the DNA primer inside the enzyme catalytic site.

So if this assumotion is true, the DNApol $\beta$ activity must be "suppressible" by $\approx 40 n$-long polynucleotides regardless on their primary structures. This would make the MIE-promoting treatment a legitimate may to gain the in situ anti-cancer molecular events.

The aim of a present study is to test this hypothesis. For this purpose, several types of synthetic single-stranded polynucleotides (both DNA- and RNA-like ones) with molecular sizes ranged in $20 n-200 n$ interval were investigated to reveal 1) their effects on catalytic activities of several beta-like DNA polymerases from HL-60, Y-79 and WERI-1A cancer cells, and 2) their enzyme-binding parameters. A selection of these peculiar cell models was determined solely by a sharp difference between the tumor proliferation rates, "aggressive" high (acute myeloid leukemia) and relatively low (retinoblastoma) [8] [9] [10] and, hence, by the difference in contributions made by the DNA repair key enzymes into the cancer cell survival capabilities.

\section{Materials and Methods}

\subsection{Reagents and Disposal Materials}

Aphidicolin (Fluka, Switzerland); ddTTP (Boehringer-Mannheim, Germany); Proteinase K (Serva, Germany); HSA (Sigma, USA); yeast tRNA (Serva, Germany); calf thymus DNA primer (Merk, Germany); dATP, dTTP, dCTP, dGTP (Serva, Germany); dioxane- and toluene-based media for liquid beta-scintillation 
count MS460 and MS710 (Merk, Germany); CS20 $25 \mathrm{~mm}$ fiberglass filters (Millipore, France); AccuPrep DNA extraction K2600 kit (Bioneer, Rep. Korea); [Methyl-1,2- ${ }^{3} \mathrm{H}$ ]dTTP, 120 - $160 \mathrm{Ci} / \mathrm{mmol}$ (Amersham, UK).

\subsection{Ligands}

Poly $(\mathrm{dT})_{25}, \operatorname{Poly}(\mathrm{dT})_{50}, \operatorname{Poly}(\mathrm{dT})_{100}$, Poly $(\mathrm{dT})_{200}$ (ThermoFisher, USA); Poly(A) ${ }_{49}$, Poly(2-thio-dC $)_{49}$, Poly(dT) $)_{40}$ (IBC RAS, Russia); Poly $(\mathrm{dT})_{40}$, Poly(dT) $)_{80}$ (ICBFM RAS, Russia); Poly $\left(\left[2-{ }^{14} \mathrm{C}\right] \mathrm{CN}-\mathrm{dT}\right)_{40}, 20-38 \mathrm{Ci} / \mathrm{mmol}$; Poly $\left(\left[2-{ }^{14} \mathrm{C}\right] \mathrm{CN}-\mathrm{dT}\right)_{80}, 20-$ $32 \mathrm{Ci} / \mathrm{mmol}$; Poly $\left(\left[5-{ }^{14} \mathrm{C}\right] \mathrm{CN}-\mathrm{dT}\right)_{40}, 18$ - $24 \mathrm{Ci} / \mathrm{mmol}$; Poly $\left(\left[5-{ }^{14} \mathrm{C}\right] \mathrm{CN}-\mathrm{dT}\right)_{80}, 16$ $22 \mathrm{Ci} / \mathrm{mmol}$ (Perkin Elmer, USA).

\subsection{Enzymes}

PAGE-homogenous beta-like monomeric, $66.5 \mathrm{kDa}$ and $23.5 \mathrm{kDa}$, DNA polymerases (EC 2.7.7.7) purified from chromatine of HL-60 acute myeloid leukemia cells [11] and WERI-1A, Y-79 retinoblastoma cells [2] were employed. Thus, to purify these chromatine-associated DNA repair programming enzymes, the following [2] [11] — promoted technique has been used. First, the chromatin fraction of the cell lysate was obtained. For this purpose, the protein containing crude nuclei phenol-chloroform extracts [2] [11] were mixed with 10 volumes of an ice-cold acetone and kept at $+4^{\circ} \mathrm{C}$ overnight. An acetone-insoluble material was precipitated at $20,000 \mathrm{rpm}, 20 \mathrm{~min},+4^{\circ} \mathrm{C}$. The pellets were extensively re-washed with acetone using the same procedure and then dissolved in $5-6$ volumes (w/v) of $25 \mathrm{mM}$ potassium-phosphate $(\mathrm{pH} 6.30) / 0.5 \% \mathrm{NaCl} / 1.5 \mathrm{mM}$ EDTA/0.01\% glutathione/0.05\% heparin/1.0\% 2-mercaptoethanol/80 - $100 \mathrm{U} / \mathrm{mL}$ nuclease $S$ followed by $40 \mathrm{~min}$ incubation at $+37^{\circ} \mathrm{C}$. All post-incubation mixtures were treated by sonication at $80 \mathrm{KHz}, 30 \mathrm{~min},+60^{\circ} \mathrm{C}$, under a non-stop extensive shaking. Then these mixtures were submitted to a scalar fractionation path reaching the $30 \%-70 \%$ ammonium sulfate saturation, consequently. The precipitates obtained were collected at 10,000 rpm, $20 \mathrm{~min}$, and dissolved in 15 $\mathrm{mM}$ potassium phosphate buffer ( $\mathrm{pH} 6.0) / 0.2 \% \mathrm{NaCl}$ (10 vols, w/v). The solutions were subjected to dialysis against $20 \mathrm{mM}$ potassium phosphate buffer $(\mathrm{pH}$ 6.0) and lyophilized.

The lyophilized powders were first dissolved in $15 \mathrm{mM}$ potassium phosphate (pH 6.30)/5.0 mM $\mathrm{MgCl}_{2} / 1.5 \mathrm{mM}$ EDTA/0.0001\% sodium azide and passed through the fiberglass filters with $0.3-0.4 \mu$ pore diameter (Millipore 5R, Millipore, France). The transparent solutions were subjected to ultrafiltration on membranes with the molecular size exclusion limit of $5.0 \mathrm{kDa}$ at 800 p.s.i. (Diaflo Y5.0 $25 \mathrm{~mm}$ membranes, Amicon BV, The Netherlands). The membrane-retained material was then extracted with $10 \mathrm{mM}$ Tris- $\mathrm{HCl}(\mathrm{pH} 8.0) / 1.0 \% 2$-mercaptoethanol (v/v), $5.0 \mathrm{~mL}$ per a razor-disintegrated membrane, $+30^{\circ} \mathrm{C}, 12 \mathrm{hrs}$, with a following concentration in a rotor evaporizer.

The $1.5-2.5 \mathrm{~mL}$ samples were then applied onto a $1.5 \times 50 \mathrm{~cm}(\mathrm{~V}=98 \mathrm{~mL})$ column packed with the TOYOPEARL HW 55F gel and equilibrated by the elu- 
ent buffer consisting of $15 \mathrm{mM}$ potassium phosphate ( $\mathrm{pH} 6.30$ )/5.0 $\mathrm{mM} \mathrm{MgCl}_{2} /$ $0.0001 \%$ sodium azide. Elution rate: $0.8 \mathrm{~mL} / \mathrm{min}$ (room temperature). In each one of the consequently eluted $1.5 \mathrm{~mL}$ fractions, the DNA polymerase activity has been measured according to [2] [11].

\subsection{Enzyme Activity Estimation}

Beta-like catalytic activity values were expressed in amounts of [3H]dTTP incorporated into nascent DNA chains in 1 min of incubation at optimal conditions corrected per $1.0 \mathrm{mg}$ of pure enzyme protein ([3H]DNAcpm/mg protein) as described in [2] [11]. The enzyme catalytic activity was measured in $0.15 \mathrm{~mL}$ incubation mixtures consisting of $50 \mathrm{mM}$ Tris- $\mathrm{HCl}(\mathrm{pH} 8.0) / 8.0 \mathrm{mM}$ dithiothreitol/15 mM $\mathrm{MgCl}_{2} / 15 \%$ glycerol (v/v)/27 $2 \mu \mathrm{g}$ act DNA, calf thymus/50 $\mu \mathrm{g}$ each of dATP, dCTP, dTTP, dGTP/0.25 $\mu$ mole [Methyl-1,2- ${ }^{3} \mathrm{H}$ ]dTTP (90 - 120 $\mathrm{Ci} / \mathrm{mmol}, \mathrm{NET} 520 \mathrm{~A}, \mathrm{NEN}) / 150 \mathrm{mM} \mathrm{NaCl}$. The tritium-labeled nucleotide was purchased from New England Nuclear, USA. These compound concentration values were first pre-optimized within both $\mathrm{pH} 6.0-9.0$ and $5.0 \mathrm{mM}-50.0 \mathrm{mM}$ $\mathrm{MgCl}_{2}$ ranges. These mixture samples were first pre-incubated at $+37^{\circ} \mathrm{C}$ for 60 min. Then $5.0-7.5 \mu \mathrm{g}$ of pure enzyme was added to each one of these running samples and they were incubated at $+37^{\circ} \mathrm{C}$ for 60 min longer. The ice cold incubation samples $\left(0^{\circ} \mathrm{C}, 60^{\circ} \mathrm{C}\right.$ after pre-incubation) as well as the trypsin treated samples $\left(20 \mu \mathrm{g} / \mathrm{mL}\right.$ trypsin, Merck $\mathrm{GmbH}$, Germany, $\left.+37^{\circ} \mathrm{C}, 60^{\circ} \mathrm{C}\right)$ were taken for controls.

The post-incubation mixtures were subjected to a quantitative extraction of the DNA ultramicro-amounts using an AccuPrep Genomic DNA Extraction Kit (Bioneer Corp., Korea).

\subsection{DNA and Protein Measurements}

The DNA ultramirco amounts measurements were performed in diluted water solutions according to [12] [13]. The protein ultramicro amounts were estimated by method [14] modified in [12].

\subsection{Radioactivity Measurements}

For $\left[{ }^{3} \mathrm{H}\right]$ and $\left[{ }^{14} \mathrm{C}\right]$ radioactivity quantitative detection, the cpm values were determined using the DNA-retaining fiberglass filters (DNApol $\beta$ post-incubation ethanol-precipitation pellets) [11] placed into dioxan or tolyene media [2] [3] [11] with a following processing in Wallac 2200LX liquid scintillation counter (Wallac, Finland).

\subsection{Ligand-Enzyme Binding Measurements}

To quantify a ligand-enzyme binding patterns, a conventional criteria such as $K_{\text {dis }}\left(K_{d}\right)$ and $A_{c}$ were taken into account.

A Baileyan model was applied for an algorithm leading to a ligand-enzyme (ligand-receptor) dissociation constant estimate [7] [15]. 
In this approach, a ligand-receptor interaction $\mathrm{R}+\mathrm{L} \underset{\beta}{\stackrel{\alpha}{\rightleftarrows}} \mathrm{RL}$, where $\mathrm{R}$ is the receptor, $\mathrm{L}$ is the ligand, $\mathrm{RL}$ is the ligand-receptor complex, $\alpha$ is the probability of formation of a complex molecule, and $\beta$ is the probability of its dissociation. If the random number of ligand-receptor complex molecules is $x$, and the initial number of receptors is $R_{0}$, the number of free receptors makes $R_{0}-x$. Assume that the process unfolds under the condition of large ligand surplus, so that the number of ligand molecules stays equal to its initial value $L_{0}$. The formation of ligand-receptor complexes is described by the function $f_{1}=\alpha L_{0}\left(R_{0}-x\right)$, and their decomposition-by $f_{-1}=\beta x$. Bailey's equation system is:

$$
\begin{aligned}
& \frac{\partial M(\theta, t)}{\partial t}=L_{0} R_{0} \alpha\left(\mathrm{e}^{\theta}-1\right) M(\theta, t)-L_{0} \alpha\left(\mathrm{e}^{\theta}-1\right) \frac{\partial M(\theta, t)}{\partial \theta} \\
& +\beta\left(\mathrm{e}^{-\theta}-1\right) \frac{\partial M(\theta, t)}{\partial \theta} \\
& \frac{\mathrm{d} k_{1}(t)}{\mathrm{d} t}=L_{0} R_{0} \alpha-L_{0} \alpha k_{1}(t)-\beta k_{1}(t), \\
& \frac{\mathrm{d} k_{2}(t)}{\mathrm{d} t}=L_{0} R_{0} \alpha-L_{0} \alpha k_{1}(t)-2 L_{0} \alpha k_{2}(t)-\beta k_{1}(t)+2 \beta k_{2}(t), \\
& k_{1}(t)=m(t)=\frac{\beta l r}{\beta l+\alpha}(1-\exp [-(\beta l+\alpha) t]), \\
& k_{2}(t)=\sigma^{2}(t)=\frac{\alpha \beta l r}{(\beta l+\alpha)^{2}}(1-\exp [-(\beta l+\alpha) t]) \\
& \left.+\frac{\beta^{2} l^{2} r}{(\beta l+\alpha)^{2}} \exp [-(\beta l+\alpha) t](1-\exp [-(\beta l+\alpha) t]]\right)
\end{aligned}
$$

Following this algorithm, an experimental data on the ligand-enzyme complexes stability in water solutions obtained by techniques described in [7] [15] and modified in [16], and affected by temperature/ultrasound/ionic strength were processed using a LQ170 SigmaLab software in HP9000 analytical system (Hewlett Packard, USA).

For a non-specific binding control, HSA and denaturated-renaturated misfolded yeast tRNA were employed as the pseudoligands [17] [18].

In all enzyme-ligand coupling tests, the enzyme required optimal catalytic parameters [2] [11] were held for $40 \mathrm{~min},+37^{\circ} \mathrm{C}$, while the following ligand concentrations kept at $0.1 \mu \mathrm{M}, 0.5 \mu \mathrm{M}, 10.0 \mu \mathrm{M}, 20.0 \mu \mathrm{M}, 50.0 \mu \mathrm{M}$, as recommended in [15] [17].

The UV-spectrophotometry (Lambda 1050 Scanning Spectrophotometer, Perkin Elmer, USA) was employed using the Spectra Manager II cross-platform software (JASCO, USA) for automated data treatment with an aim to gain the $A_{c}$ index indicating an extent of polynucleotide release from ligand-enzyme in water solution owing to a certain consent of $A_{210}, A_{254}, A_{280}$ values, $A_{c}=\left[A_{254} /\left(A_{280}-A_{254}\right)\right] / A_{210} \quad[16]$. 


\subsection{Statistics}

A Dunnett's non-parametric $(n \leq 6)$ technique was used to elucidate reproductability of the data along with a significance of differences in control-experiment comparisons [19].

\section{Results}

A variable set of polynucleotide ligands (see Methods) was tested for both inhibitory effects and the ligand-enzyme binding properties using beta-like DNA polymerase species from acute myeloid leukemia (HL-60) and retinoblastoma (WERI-1A, Y-79) cells.

As seen from the data presented in Figure 2 and Figure 3, no matter what ligand concentration tested and whatever enzyme sample coupled, a molecular size of synthetic polynucleotide is the only, crucial, impact-making factor. It should be emphasized that a maximal inhibition effects were observed in cases of 50n-100n-long polynucleotides (Figure 2(C) and Figure 2(D)), Figures $3(\mathrm{~A})-(\mathrm{E}))$, while a post-denaturation misfolded tRNA test show no inhibition

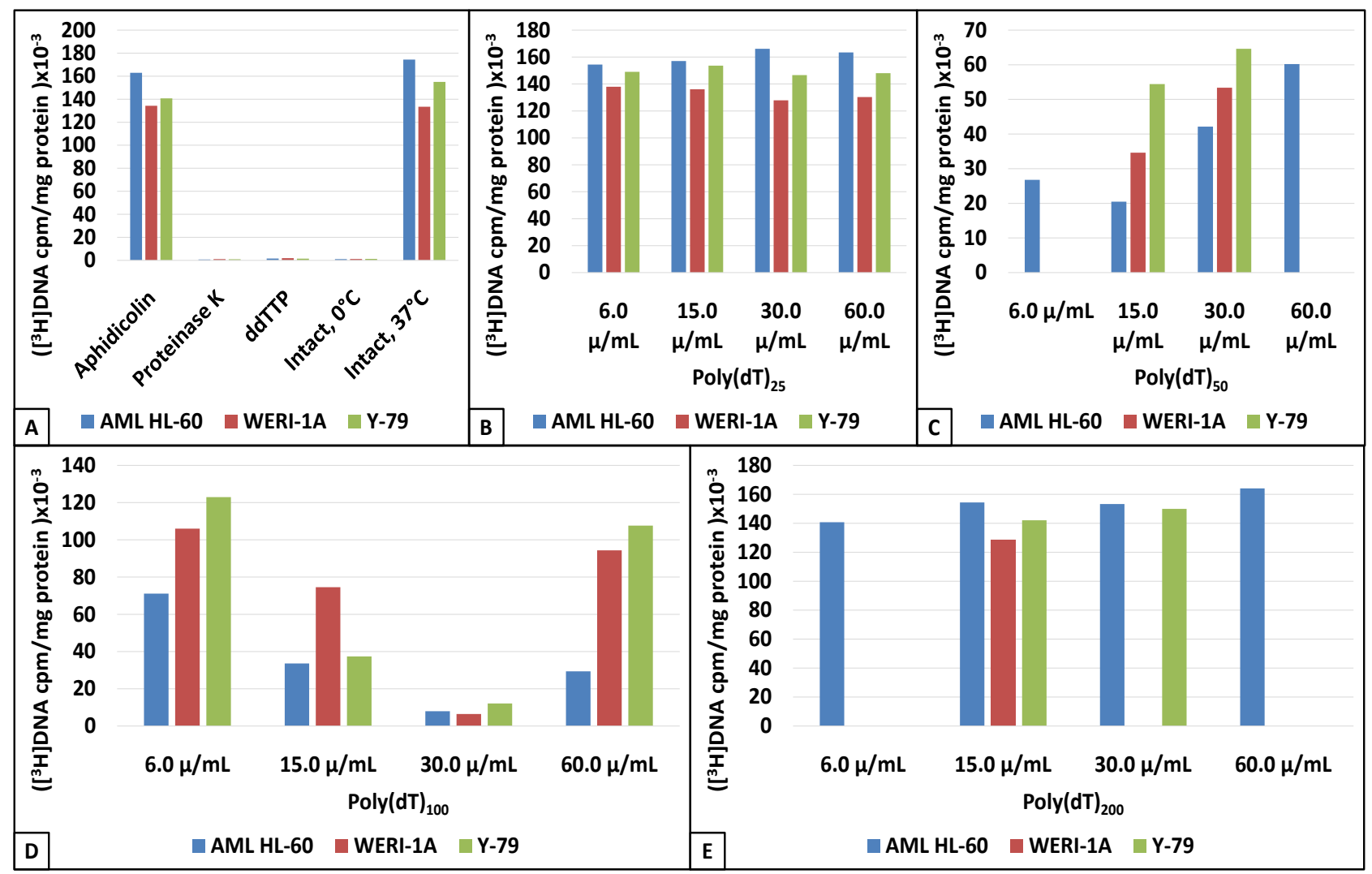

Figure 2. (A) Catalytic activities of beta-like DNA polymerases from HL-60, WERI-1A and Y-79 cancer cells under optimal and modified incubation conditions. (B) Catalytic activities of beta-like DNA polymerases from HL-60, WERI-1A and Y-79 cancer cells in the presense of Poly $(\mathrm{dT})_{25}$. (C) Catalytic activities of beta-like DNA polymerases from HL-60, WERI-1A and Y-79 cancer cells in the presense of Poly $(\mathrm{dT})_{50}$. (D) Catalytic activities of beta-like DNA polymerases from HL-60, WERI-1A and Y-79 cancer cells in the presense of Poly $(\mathrm{dT})_{100}$. (E) Catalytic activities of beta-like DNA polymerases from HL-60, WERI-1A and Y-79 cancer cells in the presense of Poly $(\mathrm{dT})_{200}$. 


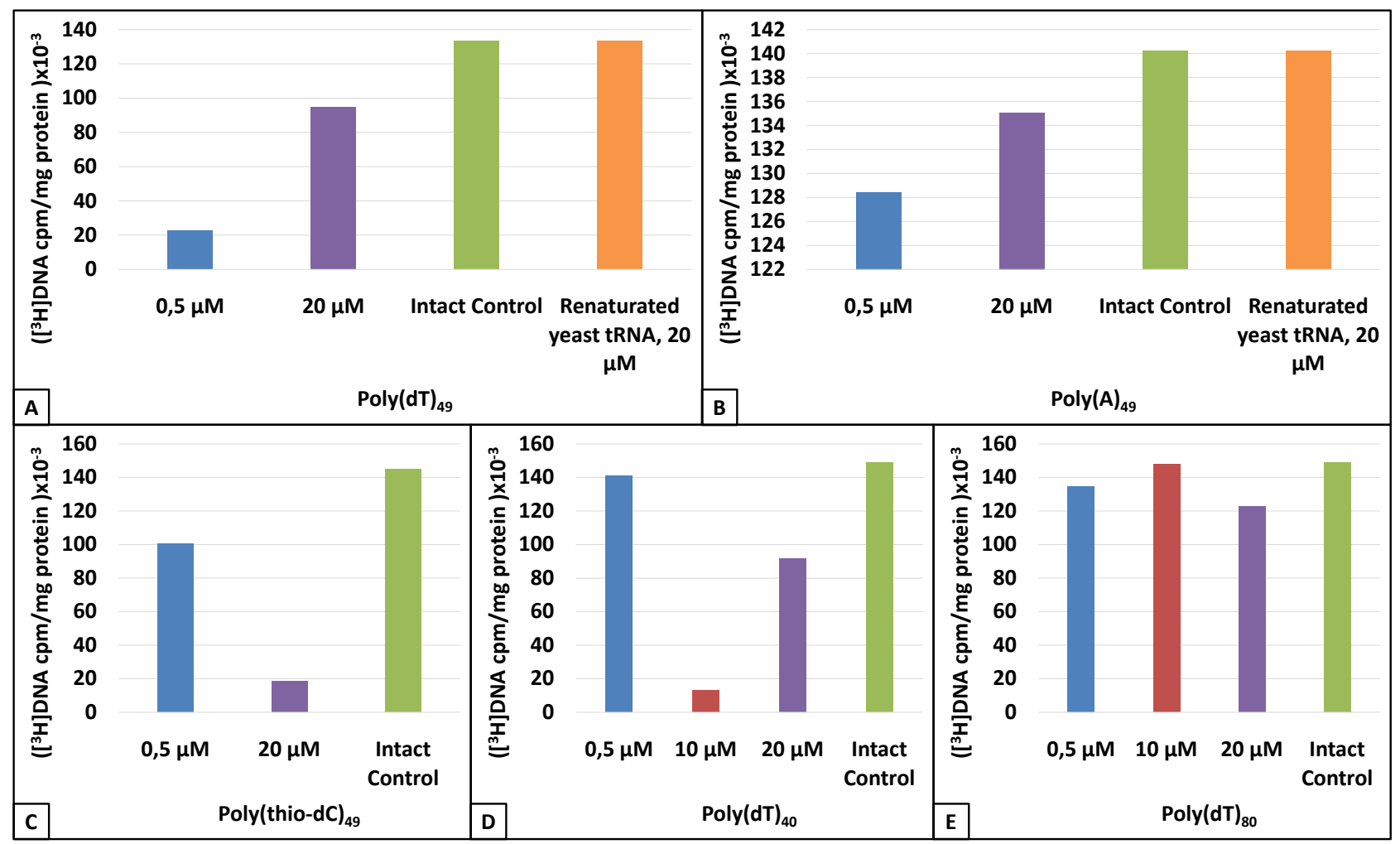

Figure 3. (A) Catalytic activity of AML/HL-60 beta-like DNA polymerase in the presense of Poly(dT) ${ }_{49}$ and renaturated yeast tRNA. (B) Catalytic activity of AML/HL-60 beta-like DNA polymerase in the presense of Poly(A) ${ }_{49}$ and renaturated yeast tRNA. (C) Catalytic activity of AML/HL-60 beta-like DNA polymerase in the presense of Poly(thio-dC ${ }_{49}$ and renaturated yeast tRNA. (D) Catalytic activity of AML/HL-60 beta-like DNA polymerase in the presense of Poly $(\mathrm{dT})_{40}$. (E) Catalytic activity of AML/HL-60 beta-like DNA polymerase in the presense of Poly $(\mathrm{dT})_{80}$.

effect at all (Figure 3(A) and Figure 3(B)). As per Aphidicolin and ddTTP controls, they just prove a true beta-specific nature of enzymes tested [2] [3] [11] (Figure 2(A)).

Unlike polydeoxyribonucleotides (PDRN), polyribonucleotides were found to be inert towards the DNApol $\beta$ processivity regardless on lengths of these ligand molecules (Figure 3(A) and Figure 3(B)).

The affinity isotherms clearly show an essential difference between the ligand-enzyme complex stability patterns, $K_{d}$ and $A_{c}$ (see Methods), estimated for numerous compositions of these couples (Figure 4 and Figure 5). Thus, dissociation constant $K_{d}$ for $\operatorname{Poly}(\mathrm{dT})_{50}$-DNApol $\beta$ was found by 2.5 -fold smaller as compared to $\operatorname{Poly}(\mathrm{dT})_{200}$-DNApol $\beta$ pair (Figure 5).

In all cases studied, except for the RNA-like Poly $(\mathrm{A})_{49}$-containing pairs (Figure 5), $K_{\mathrm{d}}$ and $\mathrm{A}_{\mathrm{c}}$ values are minimal when the ligand length is close to $50 n$ (Figure 6). For all RNA-like ligands, the high values of $K_{\mathrm{d}}$ and $\mathrm{A}_{\mathrm{c}}$ were found practically equal to the ones estimated for Poly $(\mathrm{dT})_{200}$ (Figure 5).

The data presented in Figure 2 and Figure 3 leaves no doubt about a maximal inhibitory efficiency provided by ultrashort, $40 n-50 n$ in length, cyano-polydeoxyribothymidyl derivatives. These agents are to show as high as nearly 6.5-fold extent of enzyme suppression. That does not mean, however, that 


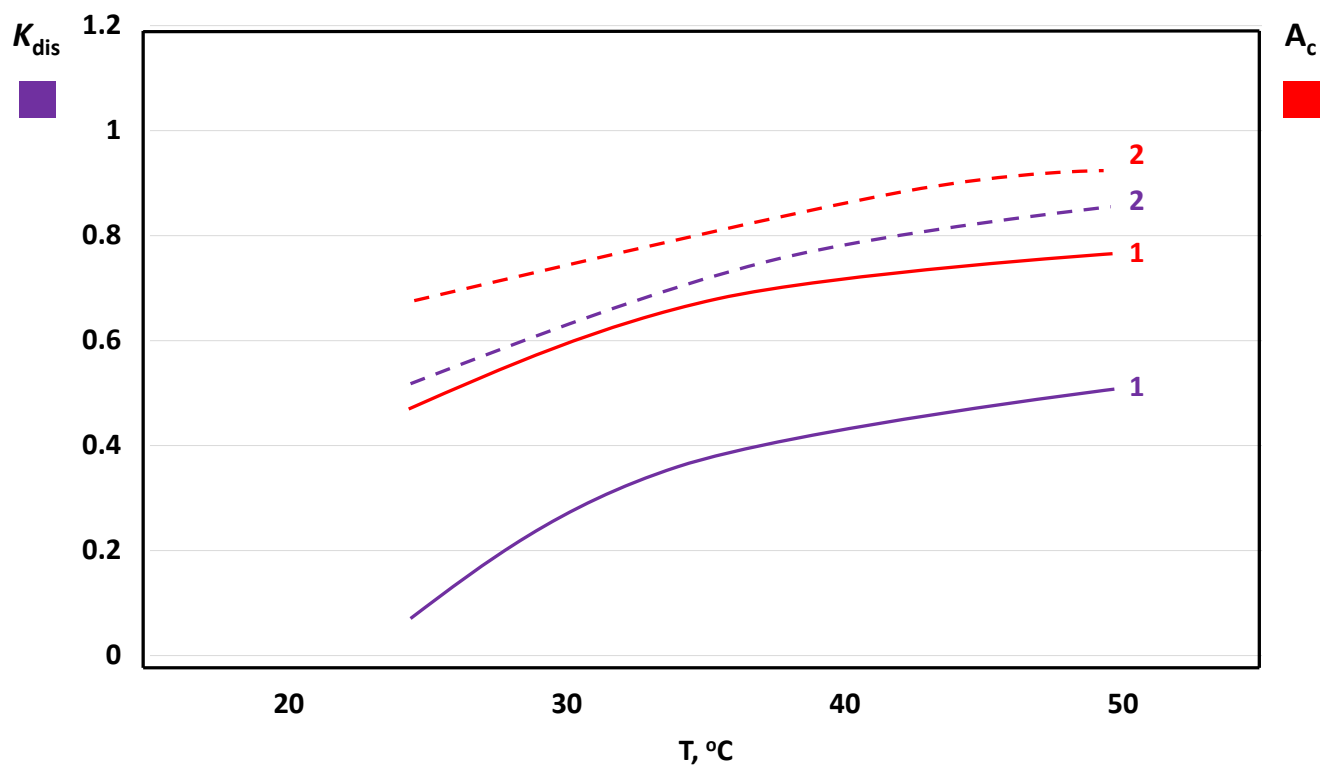

Figure 4. Affinity isotherms for HL-60-DNApol $\beta / \operatorname{Poly}(\mathrm{dT})_{50}$ (1) and HL-60-DNApol $\beta / \operatorname{Poly}(\mathrm{dT})_{200}$ (2) ligand-acceptor complexes. For technical details, see Methods.

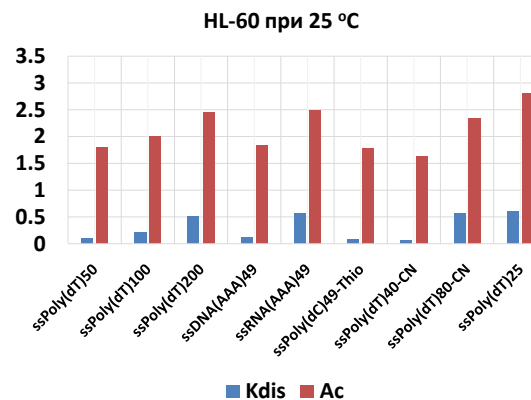

HL-60 при $50^{\circ} \mathrm{C}$

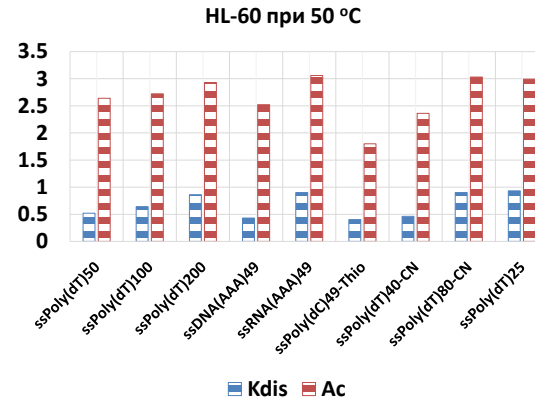

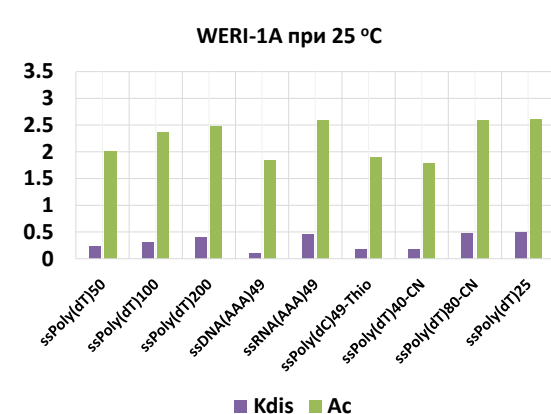

WERI-1A при $50^{\circ} \mathrm{C}$

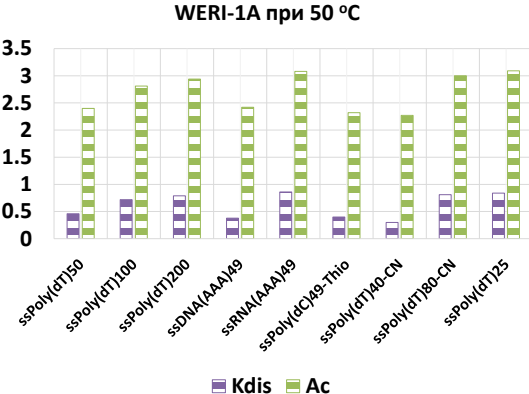

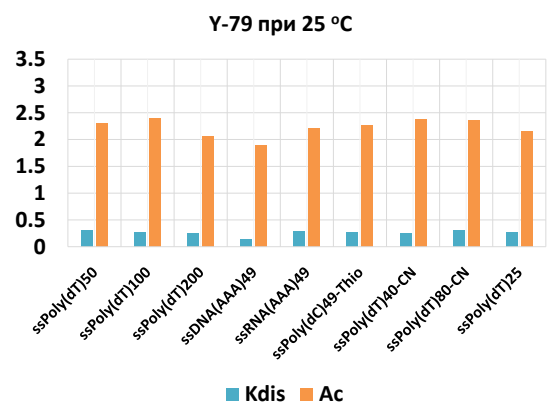

Y-79 при $50{ }^{\circ} \mathrm{C}$

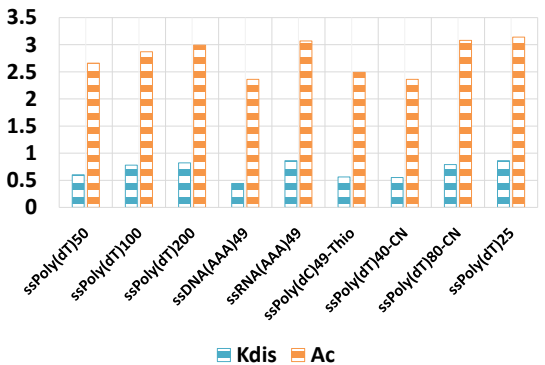

Figure 5. Polynucleotide-enzyme binding patterns $\left(K_{\mathrm{dis}}, A_{c}\right)$ estimated for beta-like DNA polymerase species from three cancer cell lines (HL-60, WERI-1A, Y-79). For technical details, see Methods.

this particular type of "pseudoprimers" is the only one capable to play a role of a powerful DNApol $\beta$ inhibitor. A truly crucial parameter to reveal a potential pharmacophore signs have nothing to do with a structure of DNA fragments being entirely related to its molecular size (Figure 2 and Figure 3 ).

So the results observed looks worthy of not indicating to any particular and perfect pharmacophore found but, instead, of a detailed analysis as a new platform to upgrade a whole approach towards the DNA derivatives in a current 


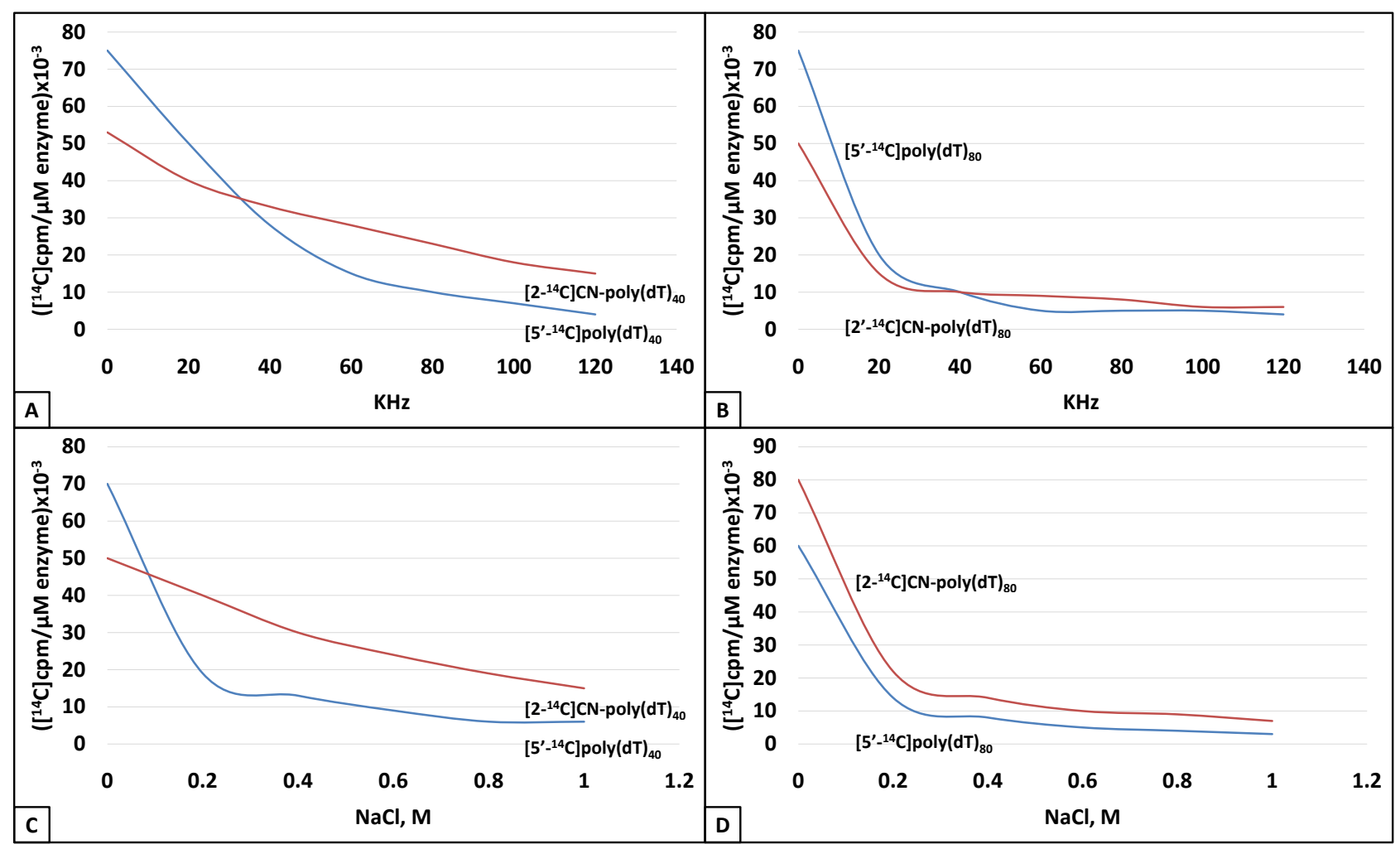

Figure 6. (A) A sonication affected stability of the couples of $\mathrm{HL}-60$ beta-like DNA polymerase and ${ }^{14} \mathrm{C}-\mathrm{labeled} \mathrm{Poly}(\mathrm{CN}-\mathrm{dT})_{40}$ evaluated by detection of free ligand release. For technical details, see Methods. (B) A sonication affected stability of the couples of HL-60 beta-like DNA polymerase and ${ }^{14} \mathrm{C}$-labeled Poly $(\mathrm{CN}-\mathrm{dT})_{80}$ evaluated by detection of free ligand release. For technical details, see Methods. (C) A salt-caused decay of the unstable complexes between HL-60 beta-like DNA polymerase and ${ }^{14} \mathrm{C}-$ labeled Poly $(\mathrm{CN}-\mathrm{dT})_{40}$ evaluated by detection of free ligand release. For technical details, see Methods. (D) A salt-caused decay of the unstable complexes between HL-60 beta-like DNA polymerase and ${ }^{14} \mathrm{C}$-labeled Poly $(\mathrm{CN}-\mathrm{dT})_{80}$ evaluated by detection of free ligand release. For technical details, see Methods.

anti-cancer agenda. This a Discussion of our work is all about.

\section{Discussion}

A wide diversity of investigated synthetic homopolynucleotides and their monotonic thio- and cyano-derivatives is itself a prove for universal, indiscriminate, mode of DNApol $\beta$ inhibition effect we described. This is in a favor with our assumption stated that the key role in this phenomenon belongs exclusively to molecular sizes of small DNA fragments regardless on their primary structure peculiarities.

The ligands diversity mentioned makes no way to explain a formation of the ligand-enzyme complexes just by a routine docking ("complimentary") paradigm. This DNA-protein binding act may involve some random appearing hydrogen bonds, Coulomb hyperfine coupling along with dispersion interaction and, last not least, the hydrophobic connections, might also be a case in this scenario. A key point of this model derives from the homopolynucleotides related data and reveals that the mean energy of these "weak" interaction depends on the length of a ligand but not of its structure. 
A similar event occurs in the DNA repair process as long as a randomly appeared local DNA damage comes first. In this case, a clearly indiscriminate mode of the ligand-enzyme coupling is a consequence of unpredictable variability in primary structures of DNA fragments suitable for the repair purposes.

Therefore, a polynucleotide length alone is an impact-making factor towards the DNApol $\beta$ catalytic function. This factor might determine a formation of the above listed "weak" non-covalent interactions and, hence, to control the mean amount of hydrogen bonds per one nucleotide of DNA-primer (ligand) inside the DNA polymerase catalytic site. That is indeed critical for the enzyme suppression in situ.

All the affinity isotherms presented and a variable ligand-enzyme binding data (Figures 4-6) reveals a maximal strength of this peculiar intermolecular interaction within the short interval of ligand sizes, $50 n-100 n$. This is to confirm that the enzyme inhibition we observed (Figures 2(B)-(E), Figure 3 ) is indeed a consequence of the stable ligand-enzyme pair formation which has nothing to do with either the solution properties changes or the enzyme surrounding disperse phase modulations.

A comparison between the ligand amounts bound with (a) DNApol $\beta$ and (b) HSA show that the ligand-enzyme complex includes two molecules of ligand per one molecule of enzyme, while the ligand-HSA (control) pair contains just one ligand per HSA molecule (Figure 4, Figure 7, Figure 8). This is in a favor to a mere fact of existance of two separate $\mathrm{Mg}^{2+}$-coordinating catalytic sites in $\beta$ - and $\beta$-like DNA polymerases [8] [10] [20] [21] [22].

Let's evaluate the activation energy value for a ligand-enzyme complex dissociation following the data listed in Figure 4 and Figure 8. Obviously, a

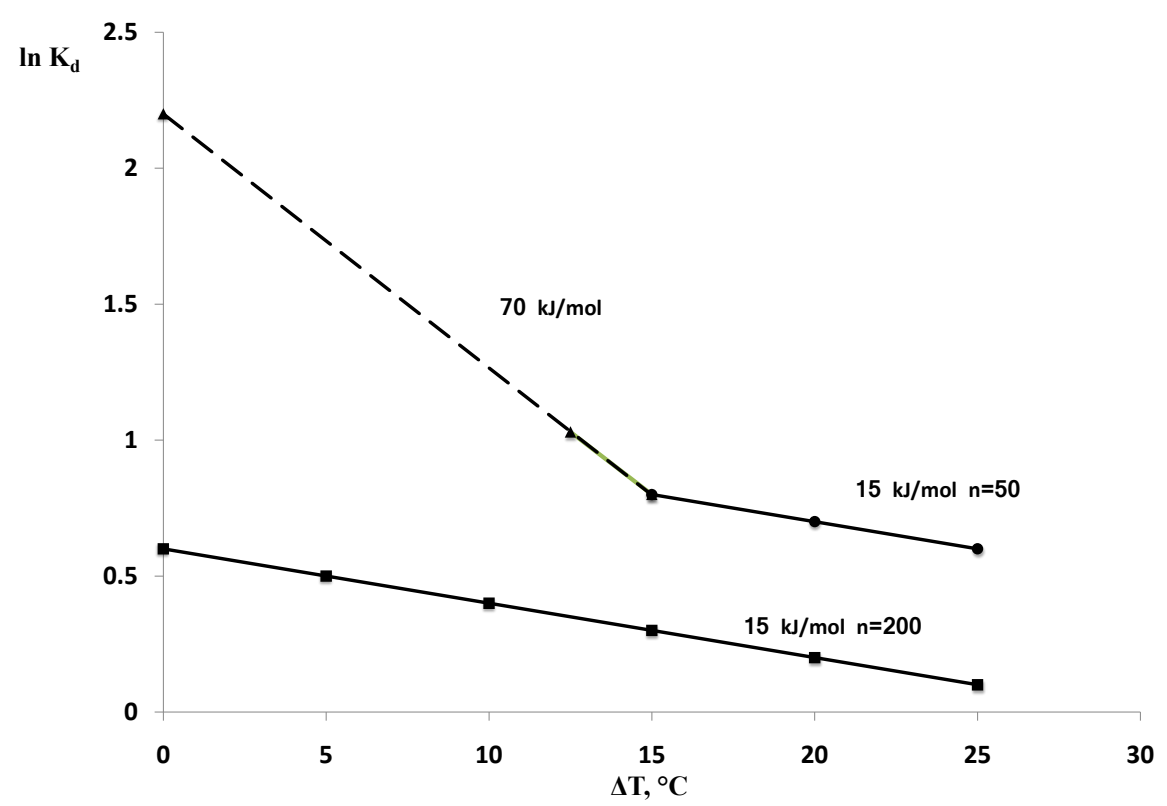

Figure 7. An activation energy of the ligand-enzyme binding as affected by temperature in DNApol $\beta$-HL60/Poly $(\mathrm{dT})_{50}$ pair formation. $\ln K_{d} \cong \ln K_{0}-E / R T_{0}+E \Delta T / R T_{0}^{2}$. See Discussion. 


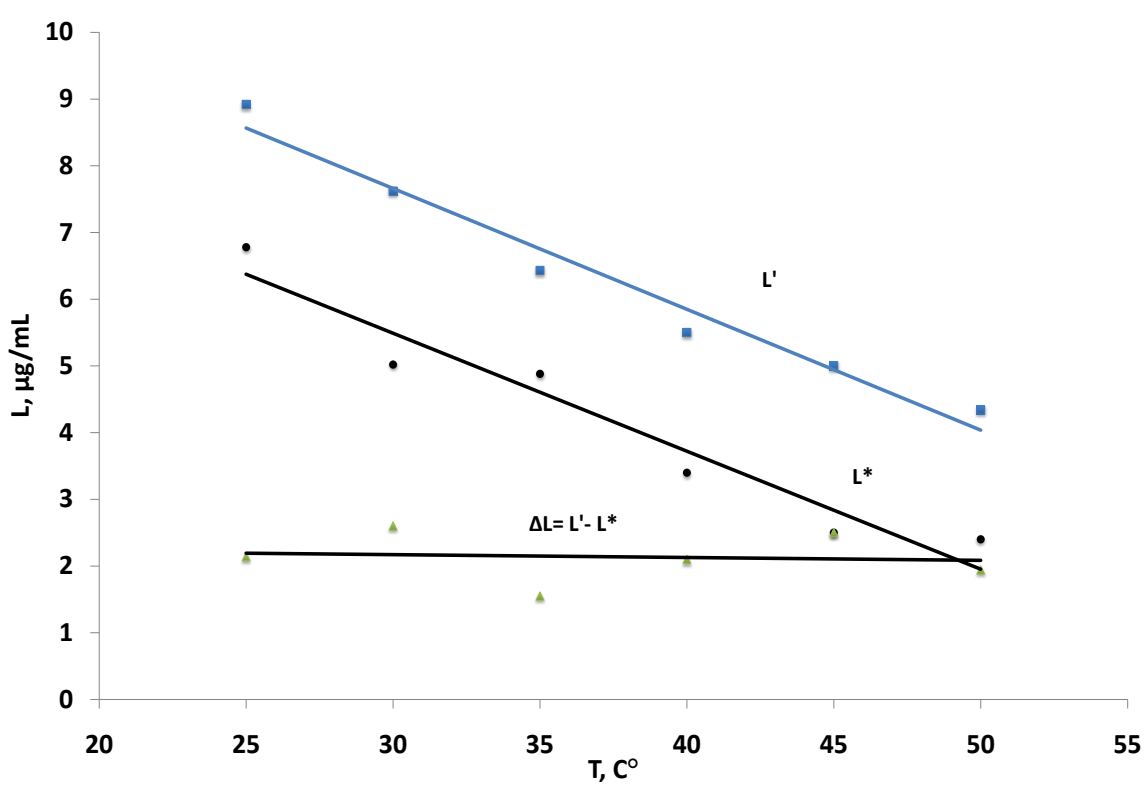

Figure 8. Temperature-dependent ligand binding in DNApol $\beta$-HL60/Poly $(\mathrm{dT})_{50}$ pair. L'-DNApol $\beta$, receptor; L*_HAS, receptor (control). For technical details, see Methods.

dependence of $K_{d}$ on temperature has a clear Ahrrenius mode:

$$
K_{d}=K_{0} \exp (-E / R T)
$$

where $R$-a universal gas constant and $T$-enzyme functioning temperature.

Taking into account a low level of the temperature interval tested as compared to an initial $T_{0}=298 \mathrm{~K}$, we'll use further a linear decay as $T$ in (1). To estimate $E$, a linear reguliarity must be treated as:

$$
\ln K_{d} \cong \ln K_{0}-E /\left(R T_{0}\right)+E \Delta T / R T_{0}^{2}
$$

where $\Delta T$ is a temperature change in experiment (Figure 7 and Figure 8).

The Equation (2) revealed activation energy value $E$ was found $15 \mathrm{~kJ}$ for Poly $(\mathrm{dT})_{200}$ ligand within a whole range of temperatures tested, while the very same dependence for Poly $(\mathrm{dT})_{50}$ include two linear branches crossing each other nearby the $40^{\circ} \mathrm{C}$ point where, most likely, a slight protein denaturation starts (Figure 7). Once the temperature is close to an enzyme function required optimal level $\left(25^{\circ} \mathrm{C}-35^{\circ} \mathrm{C}\right)$, the Equation (2) revealed $E_{50}=70 \mathrm{~kJ} / \mathrm{mole}$ whereas this value estimated at $40^{\circ} \mathrm{C}$ is as low as $15 \mathrm{~kJ} / \mathrm{mole}$ (Figure 7). The attention catching point here is that the $E$ value measured at the enzyme denaturation launch-point $\left(40^{\circ} \mathrm{C}\right)$ is exactly the same as it has been found in case of the "inert", non-inhibiting, polydeoxyribonucleotide ligands. This supports a statement on the enzyme inactivating protein structure dynamics initiated starting with a $40^{\circ} \mathrm{C}$ heating point. A lack of two-compartment, "angle-breaking", $K_{d}=f(T)$ dependence for long ligands and their $E$ values low level are in a good accordance with a high probability of 3D-compactization of such sequences at our test conditions [7] [16] [17] [23].

It's easy to find out that the inhibition-promoting Poly(dNTP) species provide 
a pretty low value of activation energy for dissociation with DNApol $\beta$-HL60, $\varepsilon=$ $1.40 \mathrm{~kJ} /$ mole. That means, the complimentary hydrogen bonds do not contribute to formation of these particular Poly(dNTP)-enzyme complexes which is a prove for the absence of the affinity-specific, true docking links in these pairs. Most probably, this remarkable $1.40 \mathrm{~kJ} /$ mole value is determined by the $U_{d}$-dispersion related weak Van der Waals interactions along with a $U_{q}$ Coulomb hyperfine coupling. These kinds of the ligand-enzyme complex stabilizing links are rather superficial ones due to both a $U_{d} \sim 1 / r^{6}$ potential and the efficient screen-like separation of Coulomb forces in water occurred within a distance smaller than $0.4 \mathrm{~nm}$ [15] [17] [23] [24]. This certainly takes into account the superficial hydrophobic bounds as well which are nothing but the result of a cooperative (cumulative) act of all the above specified forces [23] [24].

So the key role in formation of $\mathrm{Poly}(\mathrm{dNTP}) / \mathrm{DNApol} \beta$ complexes belongs to Van der Waals bounds which energy corresponds directly to either 1) the efficient surface of ligand-enzyme pair or 2) a length of an enzyme-bound ligand.

Furthermore, since the mean value of the $U_{d}$ dispersion patterns is hardly dependent on the element composition, and as long as the amounts of charged groups in $U_{q}$-determining Poly(dNTP) ligands tested are about the same, a very similar parameters of their inhibitory activity should be expected then. This explains well a lack of dependence of inhibitory capabilities of these ligands on their nucleotide composition (Figures 2(B)-(E), Figure 3).

Once $\varepsilon \sim R T$, we might suppose that the short ligands $(50 n-100 n$, or shorter) are to get bound with the enzyme molecule throughout a whole linear chain, i.e. through nearly every nucleotide of Poly(dNTP) sequence.

Using the Ahrrenius equation, we may evaluate a ratio between the ligandenzyme binding time values $\tau$ for Poly $(\mathrm{dNTP})_{20}$ and Poly $(\mathrm{dNTP})_{50}$, respectively:

$$
\tau_{20} / \tau_{50}=\exp (-\Delta n \varepsilon / R T) \cong 10^{-7}
$$

where $\Delta=30$ (difference in lengths between $50 n$ and $20 n$ ). It shows that a short time of binding $\tau_{20}$ does not allow $n_{20}$-ligand to promote a sharp suppression of the enzyme activity. A shorter time for the ligand "neighboring" around the enzyme catalytic site, the lesser inhibitory effect to be expressed.

On other hand, the longest ligands tested were found to be a rather poor inhibitors as well (Figure 2(E), Figure 4) due to their compactization-caused small square of the enzyme-ligand efficient interaction [23] [25] as also seen from Equation (3).

As per a zero inhibition affect shown by RNA-like ligands tested (Figure 3(A) and Figure 3(B)), their remarkable refolding capabilities [18] [25] and [O----- $\mathrm{Mg}^{2+}$ ] coordination input [26] [27] are presumably beyond this phenomenon.

A clear pharmacological potential of oligo- and polydeoxyribinucleotides is a subject for numerous experimental and clinical studies performed since early 1990s [18] [27] [28] [29] [30]. Their applied medicinal significance, however, were treated predominantly by focusing on the aptomer properties, i.e. on capa- 
bilities to find the specific target molecules such as signaling proteins, membrane receptors, chromatin structure elements, etc [17] [26] [28] [30] [31]. Unlike our present work, therefore, these studies are all about the true docking participants. The inhibitory power of Poly(dNTP) species we found has nothing to do with their structures and composition being entirely dependent on molecular size (Figures 2(B)-(E), Figure 3(A), Figure 3(C), Figure 3(D), Figure 3(E)). This allows to "turn the page" in a long record of polynucleotide medicinal applications by just paying attention to the Poly(dNTP) motion on how to shut down a DNA repair in malignant cells. It makes sense for DNApol $\beta$, key DNA repair enzymes, are found hyperexpressed in response to a high frequency of DNA damages followed by an increase of the cancer related cell proliferation rate [2] [3] [10] [11] [20]. With a respect to this statement, it has been already emphasized that the members of this enzyme family are the "legitimate targets" for cytostatic inhibitors like dNTP antimetabolites [8] [9] [10] [28] [32] and magnetic metal isotopes [1] [2] [3] [24].

There is a good enough understanding on molecular mechanisms beyond the inhibition of the cancer-hyperexpressed DNApol $\beta$ species provided by magnetic isotopes of bivalent metals $-{ }^{25} \mathrm{Mg},{ }^{43} \mathrm{Ca}$ and ${ }^{67} \mathrm{Zn}$ [1] [2] [3] [9] [24]. In particular, these mechanisms are dealing with the origin of "too short", DNA repair insufficient, DNA fragments [1] [2] [3]. This effect leads to a massive release of the DNA repair related $40 n-100 n$ DNA sequences with the unpredictable, unique structures [1] [2], i.e. this provokes a magnetic isotope induced formation of the DNApol $\beta$ endogenous inhibitors. It looks like a good explanation for cytostatic activity shown by magnetic metal isotopes in several cancer cells [1] [24].

Everything we know about pharmacokinetics of various DNA-based drugs and pharmacophores indicates to the fact that their bioavailability is far of being perfect mostly because of inevitable nucleases attack [18] [27] [28] [29] [30]. So this is the hardest task to manage a targeted delivery of Poly(dNTP) sequences to the DNApol $\beta$-operating in situ compartments, for which some certain nanocarriers required [7] [18] [30] [33]. As for the magnetic metal ions, they can be delivered to the DNApol $\beta$ in situ targets with [1] [24] or even without [2] [3] nanocationite administration which would make the magnetic isotope effect a promising tool to gain the DNA repair machinery breakdown in neoplasma.

Knowing that the abundance of ${ }^{25} \mathrm{Mg}$ is relatively high $(\approx 10 \%)$ and considering a remarkable role of magnesium in enzymatic phosphorylation processes [1] [24] [34], it would be logical to suppose the existence of so called "hidden" effects of Magnesium-25 on numerous metabolic pathways. In this case, a high content of endogenous $\mathrm{Fe}^{2+}$ in cells and tissues of a living organism becomes a natural limiting factor to prohibit any expression of magnetic isotope effects in vi$v o$. This is in accordance with the data on correlations between the ${ }^{25} \mathrm{Mg}^{2+}$-affected ATP synthesis levels in mitochondria and the $\mathrm{Fe}^{2+}$ contents in these mitochondria isolated from different rat tissues [34] as well as with the results stated an increase of $\mathrm{Fe} / \mathrm{Mg}$ ratios in several types of cancer (ovarian cancer, renal adeno- 
carcinoma, fibroblast lung cancer, hepatocellular cancer, osteosarcoma, thyroid follicular adenocarcinoma) compared to corresponding normal, non-malignant, tissues [9] [20] [26] [32].

A variety of clinical case reports showing an appearance of short (100n-300n) single-stranded DNA fragmets in a blood plasma of oncology patients [26] [35] may now also be treated under a point of view of the probable DNA repair related origin of these tumor-released Poly(dNTP) sequences.

Last not least, the infamous quorum sensing phenomena [36] could be engaged with an effort to uncover a biological meaning of what we've found testing the capabilities of different Poly(dNTP) species to affect some tumor-specific DNA repair key enzymes.

\section{Conclusions}

Ultrashort $(40 n-100 n)$ polydeoxyribonucleotides are found to be the efficient non-specific inhibitors of DNA polymerases $\beta$ from chromatin of several cancer cells: HL-60, WERI-1A, Y-79.

Manifesting a positive correlation between these inhibitory capabilities and the strength of affinity in enzyme-ligand pairs, such poly(dNTP) species promote a sharp suppression of enzymatic catalysis regardless on their primary structures. Only molecular size matters.

The data presented show a clear regulatory potential of some short ssDNA entities once they are about to interact with the key DNA repair enzymes.

This may provide a promising platform for further research aiming to shut down the DNA repair machinery in malignancies.

\section{Acknowledgements}

This work was performed within the aims and scope of the Russian Federal Specialized Program on priorities in science and technologies trends for 2014-2020 supported by Russian Federal Ministry of Science and University Education. The RF Government budget beyond.

\section{Conflicts of Interest}

The authors declare no conflicts of interest regarding the publication of this paper.

\section{References}

[1] Buchachenko, A.L., Bukhvostov, A.A., Ermakov, K.V. and Kuznetsov, D.A. (2019) Nuclear Spin Selectivity in Enzymatic Catalysis. A Caution for Applied Biophysics. Archives of Biochemistry and Biophysics, 667, 30-35. https://doi.org/10.1016/j.abb.2019.04.005

[2] Bukhvostov, A.A., Dvornikov, A.S., Ermakov, K.V., Kurapov, P.B. and Kyznetsov, D.A. (2017) Retinoblastoma: Magnetic Isotope Effects Might Make a Difference in the Current Anti-Cancer Research Strategy. Acta Medica (Hradec Kralove), 60, 93-96. https://doi.org/10.14712/18059694.2017.101 
[3] Bukhvostov, A.A., Dvornikov, A.S., Ermakov, K.V. and Kuznetsov, D.A. (2017) Retinoblastoma Case: Shall We Get a Paramagnetic Trend in Chemotherapy? Archives of Cancer Research, 5, 158-162. https://doi.org/10.21767/2254-6081.100158

[4] Chen, S.J. (2019) Site-Specific Binding of Non-Site-Specific Ions. Biophysical Journal, 116, 38-46. https://doi.org/10.1016/j.bpj.2019.04.038

[5] Muller, W.E., Obermeyer, J. and Totsuka, A. (1974) Influence of Template Inactivators on the Binding of DNA Polymerases to DNA. Nucleic Acids Research, 1, 63-69. https://doi.org/10.1093/nar/1.1.63

[6] Corces, M.R., Granja, J.M., Shams, S., Louie, B.H., Seoane, J.A., Zhou, W., Silva, T.C. and Chang, H.V. (2018) The Chromatin Accessibility Landscape of Primary Human Cancers. Science, 362, 16-28. https://doi.org/10.1126/science.aav1898

[7] Ashley, J.S., Kronenberg, G.H., Lipman, K.R. and Bielka, H. (2019) Coupling the DNA Turnover Enzymes. Poly(dNMP) Ligands. In: Pitot, H. and Van Nijemen, J.T. Eds., Methods in Macromolecular Docking Research, University of Ghent Press, Ghent-Antwerp, 216-229.

[8] Turgeon, M.O., Perry, N.J.S. and Poulogiannis, G. (2018) DNA Damage, Repair and Cancer Metabolism. Frontiers in Oncology, 8, 15-22.

https://doi.org/10.3389/fonc.2018.00015

[9] Breitenbach, M. and Hoffmann, J. (2018) Cancer Models. Frontiers in Oncology, 8, 401-419. https://doi.org/10.3389/fonc.2018.00401

[10] Jain, R., Aggarwal, A.K. and Rechkoblit, O. (2018) Eukaryotic DNA Polymerases. Current Opinion in Structural Biology, 53, 77-87. https://doi.org/10.1016/j.sbi.2018.06.003

[11] Bukhvostov, A.A., Shatalov, O.A., Orlov, A.P. and Kuznetsov, D.A. (2013) An Atypical DNA Polymerase Beta Overexpressed in Human AML/HL-60 Malignant Cells. Journal of Cancer Science and Therapy, 5, 94-99. https://doi.org/10.4172/1948-5956.1000191

[12] Katoh, R. (2011) Analytical Techniques in Biochemistry and Molecular Biology. Springer Publ. GmbH, Berlin-Heidelberg.

[13] Dewar, J.M. and Lyndall, D. (2012) Simple Non-Radioactive Measurement of Single-Stranded DNA. In: Bjergbaek, L., Ed., Methods in Molecular Biology, DNA Repair Protocols, Humana Press, Inc., Totowa, 920, 341-349. https://doi.org/10.1007/978-1-61779-998-3_24

[14] Fukami, T., Uchiyama, K. and Yoshimura, Y. (1996) Ultramicroanalysis by Use of Light-Scanning Photoacoustic Densitometry of Electrophoresed Protein. Analytical Biochemistry, 238, 60-67. https://doi.org/10.1006/abio.1996.0251

[15] Rastogi, C., Rube, H.T., Kribelbauer, J.F., Crocker, J., Locker, R.E., Martini, G.D. and Laptenko, O. (2018) Accurate and Sensitive Quantification of Protein-DNA Binding Affinity. PNAS, 115, E3692-E3701. https://doi.org/10.1073/pnas.1714376115

[16] Laurent, C., Neurath, K.J., Baglioni, G. and Sieliwanowicz, B. (2019) Advances in Multiwave UV-Spectrophotometry: RNP/DNP Integrity Studies. In: Lindsey, A.L. and Cohen, K., Eds., Physics of Biopolymers, Adler \& Adler Publ., Perth, 41-56.

[17] Chowdhury, N. and Bagchi, A. (2015) An Overview of DNA-Protein Interactions. Current Chemical Biology, 9, 71-83. https://doi.org/10.2174/2212796809666151022202255

[18] Telashima, Y. (2019) Revival of Oligonucleotide Therapy Development. KOKEN Publ., Tokyo-Nagoya. 
[19] Byron, W.M., Hollander, B. and Hollander, M. (2007) Statistics. A Biomedical Introduction. Wiley-Blackwell Publ., Oxford-Weinheim.

[20] Lavrik, I.N. (2014) Systems Biology of Death Receptor Networks: Live and Let Die. Cell Death \& Disease, 5, e1259-e1266. https://doi.org/10.1038/cddis.2014.160

[21] Peterson, L.E. (2019) Small Molecule Docking of DNA Repair Proteins Associated with Cancer Survival Following PCNA Metagene Adjustment. A Potential Novel Class of Repair Inhibitors. Molecules, 24, 645-667. https://doi.org/10.3390/molecules24030645

[22] Wu, Y., Lu, J. and Kang, T. (2016) Human Single-Stranded DNA Binding Proteins: Guardians of Genome Stability. Acta Biochimica et Biophysica Sinica, 48, 671-677. https://doi.org/10.1093/abbs/gmw044

[23] Finkelsten, A.V. and Ptitsyn, O.V. (2012) Physics of Proteins. Nova Publ., Princeton.

[24] Buchachenko, A.L. (2015) Magneto-Biology and Medicine. Nova Science Publ., New York.

[25] Morten, M.J., Gamsjaejer, R., Cubeddu, L., Kariawasam, R., Peregrina, J., Penedo, J.C. and White, M.F. (2017) High Affinity RNA Binding by a Hyperthermophilic Single-Stranded DNA-Binding Protein. Extremophiles, 21, 369-379. https://doi.org/10.1007/s00792-016-0910-2

[26] Lyu, J., Wang, S., Balius, T.E., Singh, I., Levit, A., Moroz, Y.S. and O’Meara, M.J. (2019) Ultra-Large Library Docking for Discovering New Chemotypes. Nature, 566, 224-229. https://doi.org/10.1038/s41586-019-0917-9

[27] Ueda, S., Watanabe, I. and Taichi, K. (2019) Nucleic Acid-Based Drugs. Sumitomo Chemical Co. Ltd., Utajima-Osaka.

[28] Udvardi, L. and Lakatos, S. (2019) Aptamers. Towards the Pharmacological Breakthrough. Alba Regia, Szegen-Budapest.

[29] Zavyalova, E., Samoylenkova, N., Revishchin, A., Turashev, A., Gordeychuk, I., Golovin, A., Kopylov, A. and Pavlova, G. (2017) The Evaluation of Pharmacodynamics and Pharmacokinetics of Anti-Thrombin DNA Aptamer RA-36. Frontiers in Pharmacology, 8, 922-930. https://doi.org/10.3389/fphar.2017.00922

[30] Squadrito, F., Bitto, A., Irrera, N., Pizzino, G., Pallio, G., Minutoli, L. and Altavilla, D. (2017) Pharmacological Activity and Clinical Use of PDRN (Polydeoxyribonucleotides). Frontiers in Pharmacology, 8, 224-233. https://doi.org/10.3389/fphar.2017.00224

[31] Ashton, N.W., Bolderson, E., Cubeddu, L., O’Byrne, K.J. and Richard, D.J. (2013) Human Single-Stranded DNA Binding Proteins Are Essential for Maintaining Genomic Stability. BMC Molecular Biology, 14, 1-20.

https://doi.org/10.1186/1471-2199-14-9

[32] Bozic, I. and Nowak, M.A. (2017) Resisting Resistance. Annual Review of Cancer Biology, 1, 203-221. https://doi.org/10.1146/annurev-cancerbio-042716-094839

[33] Ansari, A.S., Santerre, P.J. and Uludag, H. (2017) Biomaterials for Polynucleotide Delivery to Anchorage-Independent Cells. Journal of Materials Chemistry B, 5, 7238-7261. https://doi.org/10.1039/C7TB01833A

[34] Svistunov, A.A., Napolov, Y.K., Bukhvostov, A.A., Shatalov, O.A., Alayutdin, R.N. and Kuznetsov, D.A. (2013) The Mitochondria Free Iron Content to Limit an Isotope Effect of ${ }^{25} \mathrm{Mg}^{2+}$ in ATP Synthesis: A Caution. Cell Biochemistry and Biophysics, 66, 417-419. https://doi.org/10.1007/s12013-012-9486-3

[35] Mouliere, F., Chandrananda, D., Piskorz, A.M., Moore, E.K., Morris, J., Ahlborn, 
L.B. and Rosenfeld, N. (2018) Enhanced Detection of Circulating Tumor DNA by Fragment Size Analysis. Science Translational Medicine, 10, 117-129.

[36] Catachura, S.C., Leys, N. and Mastroleo, J. (2018) Quorum Sensing in Life Support Systems. In: Kalia, V.C., Ed., Quorum Sensing, Springer Nature, Ltd., Singapore, 249-260. https://doi.org/10.1007/978-981-13-0848-2_16

\section{Abbreviations}

ssDNA, Single-Stranded DNA;

DNApol $\beta$, DNA Polymerase Beta;

MIE, Magnetic Isotope Effects;

AML, Acute Myeloid Leukemia. 